(C) 2014

\author{
Ляиенко А. О., аспірант
}

(науковий керівник - доктор сільськогосподарських наук, професор, академік НААНУ М. I. Бащенко)

Черкаська дослідна станція біоресурсів НААНУ

\title{
МОРФОЛОГІЧНИЙ АНАЛІЗ СПЕРМИ БУГАЇВ ДОВГОТРИВАЛОГО ЗБЕРІГАННЯ
}

\section{Рецензент - кандидат сільськогосподарських наук О. Ф. Гончар}

\begin{abstract}
Проведено дослідження морфологічних характеристик деконсервованих сперматозоїдів бугаїв різних порід Банку генетичних ресурсів за умов довготривалого зберігання в рідкому азоті. Встановлено вірогідну різницю між показниками патологічних $і$ мертвих форм спермїв бугаїв за різних термінів зберігання. У результаті проведених досліджень (за термінів зберігання 10-45 років) у бугаӥв молочних порід спостерігались вищі за норму значення патологічних форм сперматозоїдів у середньому на 2,5\%, окрім сперми української чорно-рябої молочної породи, а у спермі бугаїв симентальської та м'ясних порід вищі у середньому на $5 \%$.
\end{abstract}

Ключові слова: кріоконсервована сперма, морфологічні характеристики сперматозоїдів, патологічні форми, довготривале зберігання, порода.

Постановка проблеми. Збереження генетичних ресурсів плідників локальних порід має неабияке значення у розведенні й підтриманні біорізноманіття. Повноцінна реалізація заходів зі збереження племінних ресурсів сільськогосподарських тварин забезпечується на основі створення генофондових стад у поєднанні 3 кріоконсервацією та довготривалим зберіганням генетичного матеріалу в кріобанках [2].

Важливо проводити періодичний моніторинг якості генетичних ресурсів для встановлення доцільності їх подальшого зберігання та можливості використання в селекційному процесі.

Аналіз основних досліджень і публікацій, у яких започатковано розв'язання проблеми. В умовах наднизьких температур рідкого азоту обмінні процеси в сперматозоїдах уповільнюються в мільйони разів.

Довготривале зберігання сперми набуває все більшого значення у зв'язку з можливістю збереження генофонду порід, типів і ліній зникаючих i рідкісних тварин $[4,6]$. Експериментальними дослідженнями окремих авторів установлено, що показники рухливості, виживаності та запліднювальної здатності глибокозамороженої сперми бугаїв залишаються на високому рівні за зберігання близько 10 років $[3,5,8]$. Одним з основних показників, який може характеризувати запліднюючу здатність сперми, $\epsilon$ іï морфологія. Морфологічні зміни можуть стосуватися всіх ділянок сперматозоїда. Більшість морфологічних порушень сперматозоїдів пов'язані між собою і призводять до зниження рухливості сперми $[1,7,9,10]$.

У літературних джерелах зустрічається недостатньо інформації стосовно морфології кріоконсервованої сперми бугаїв різних порід залежно від тривалості зберігання, що й обумовлює актуальність наших досліджень у даному напрямі.

Мета і завдання досліджень. Мета: дослідити морфологічні характеристики сперматозоїдів бугаїв різних порід за умов довготривалого зберігання сперми в рідкому азоті.

Завдання: провести оцінку морфології сперми бугаїв Банку генетичних ресурсів IРГТ НААН.

Матеріал і методика проведення досліджень. У дослідженнях використовували кріоконсервовану сперму 85 бугаїв дев'яти порід. Термін зберігання досліджуваних спермодоз становив від 10 до 45 років. Сперму бугаїв розділили на три групи: перша - 3 термінами зберігання 10-20 років, друга $-21-30$ років і третя -31-45 років.

Дослідження морфологічних характеристик сперматозоїдів бугаїв проводили в лабораторії племпідприємства Черкаського ПрАТ НВО «Прогрес» із використанням мікроскопа Olympus CX-31. Визначення відсотка живихмертвих сперматозоїдів і показників морфології сперматозоїдів бугаїв проводили за загальноприйнятою методикою. Під мікроскопом визначали кількість сперматозоїдів із відхиленнями у будові головки, шийки, тіла та хвоста.

Результати досліджень. За результатами досліджень встановлено, що за термінів зберігання 10-45 років спостерігалися вищі за норму значення патологічних форм сперматозоїдів бугаїв молочних порід, у середньому на $2,5 \%$, окрім сперми української чорно-рябої молочної породи, а у спермі бугаїв симентальської та м'ясних порід вищі у середньому на $5 \%$. 
СТОРІНКА МОЛОДОГО ВЧЕНОГО

\begin{tabular}{|c|c|c|c|c|c|}
\hline \multicolumn{6}{|c|}{$\begin{array}{l}\text { 1. Характеристика морфологічно-змінених форм сперматозоӥдів бугаӥв } \\
\text { окремих порід за термінів зберігання 10-20 років, \% }\end{array}$} \\
\hline \multirow{2}{*}{$\begin{array}{l}\text { Вид патології } \\
\text { спермія }\end{array}$} & \multicolumn{5}{|c|}{ Порода $\left(\mathrm{M} \pm \mathrm{m} / \mathrm{C}_{\mathrm{v}}\right)$} \\
\hline & симентальська & голштинська & УЧР & УЧЕР & англерська \\
\hline Мертві спермії & $\begin{array}{l}32,0 \pm 1,7 \\
27,6\end{array}$ & $\begin{array}{l}32,0 \pm 2,5 \\
31,6\end{array}$ & $\begin{array}{c}24,1 \pm 1,3^{*} \\
18,7\end{array}$ & $\begin{array}{l}31,6 \pm 1,2 \\
28,0\end{array}$ & $\begin{array}{c}27,1 \pm 3,7 \\
43,7\end{array}$ \\
\hline Патології головок & $\begin{array}{c}7,2 \pm 0,2 \\
15,5\end{array}$ & $\begin{array}{c}6,3 \pm 0,2 \\
15,7\end{array}$ & $\begin{array}{c}5,7 \pm 0,2 \\
10,0\end{array}$ & $\begin{array}{c}6,0 \pm 0,1 \\
15,4\end{array}$ & $\begin{array}{l}7,3 \pm 0,2 \\
9,8\end{array}$ \\
\hline Патології хвостів & $\begin{array}{c}7,3 \pm 0,2 \\
15,5\end{array}$ & $\begin{array}{c}6,5 \pm 0,2 \\
15,8\end{array}$ & $\begin{array}{l}5,6 \pm 0,2 \\
9,6\end{array}$ & $\begin{array}{c}6,0 \pm 0,1 \\
15,9\end{array}$ & $\begin{array}{c}7,0 \pm 0,3 \\
11,7\end{array}$ \\
\hline Патології шийок & $\begin{array}{c}2,0 \pm 0,1 \\
17,2\end{array}$ & $\begin{array}{c}1,6 \pm 0,1 \\
12,7\end{array}$ & $\begin{array}{c}1,7 \pm 0,1 \\
11,6\end{array}$ & $\begin{array}{c}1,7 \pm 0,1 \\
18,9\end{array}$ & $\begin{array}{c}2,1 \pm 0,1 \\
9,0\end{array}$ \\
\hline Патології тіл & $\begin{array}{c}2,1 \pm 0,1 \\
14,9\end{array}$ & $\begin{array}{c}1,7 \pm 0,1 \\
10,2\end{array}$ & $\begin{array}{c}1,6 \pm 0,1 \\
13,7\end{array}$ & $\begin{array}{c}1,8 \pm 0,1 \\
19,8\end{array}$ & $\begin{array}{c}2,0 \pm 0,1 \\
7,0\end{array}$ \\
\hline $\begin{array}{l}\text { Інші види } \\
\text { патологій }\end{array}$ & $\begin{array}{c}3,9 \pm 0,1 \\
17,3\end{array}$ & $\begin{array}{c}3,6 \pm 0,1 \\
12,5\end{array}$ & $\begin{array}{c}3,3 \pm 0,1 \\
13,7\end{array}$ & $\begin{array}{c}3,7 \pm 0,1 \\
19,0\end{array}$ & $\begin{array}{c}3,4 \pm 0,1 \\
15,7\end{array}$ \\
\hline $\begin{array}{c}\text { Сума патологіч- } \\
\text { них форм }\end{array}$ & $\begin{array}{c}22,4 \pm 0,6 \\
13,5\end{array}$ & $\begin{array}{c}19,8 \pm 0,5 \\
10,4\end{array}$ & $\begin{array}{c}17,8 \pm 0,4^{*} \\
8,5\end{array}$ & $\begin{array}{c}19,2 \pm 0,4 \\
14,5\end{array}$ & $\begin{array}{c}21,7 \pm 0,7 \\
9,4\end{array}$ \\
\hline
\end{tabular}

Примітка: ${ }^{*}-\mathrm{p}<0,05$

Визначено, що найнижчий відсоток мертвих сперміїв і патологічних форм спостерігався у спермі бугаїв УчР, що вірогідно нижче в середньому на $5 \%$, аніж у бугаїв інших порід за терміну зберігання $10-20$ років $(\mathrm{p}<0,05)$.

Для сперми української червоно-рябої молочної породи (далі- УЧЕР) характерна більша кількість мертвих і патологічних форм сперміїв у середньому на $4,5 \%$, ніж у спермі бугаїв УЧР $(\mathrm{p}<0,05)$. Відповідно, у спермі бугаїв голштинської породи було більше мертвих і патологічних форм у середньому на $5 \%$, ніж у спермі бугаїв УЧР $(\mathrm{p}<0,01)$.

Встановлено, що відсоток патологічних форм у спермі бугаїв англерської породи був вищий у середньому на $3,2 \%$, аніж у бугаїв вищезгаданих молочних порід $(p<0,01)$. Слід зазначити, що відсоток патологічних форм у спермі бугаїв симентальської породи за терміну зберігання 10-20 років був вищий у середньому на $4 \%$, ніж у бугаїв українських молочних порід ( $<0,01)$ (табл. 1).

Встановлено, що відсоток мертвих і патологічних форм сперміїв бугаїв породи лімузин за терміну зберігання 10-20 років виявився вищим у середньому на $4,6 \%$, аніж у бугаїв волинської та української м'ясних порід $(\mathrm{p}<0,05)$. Визначено, що для сперматозоїдів бугаїв породи лімузин характерна вірогідно нижча кількість сперматозоїдів із патологією головки в середньому на $1,4 \%$, аніж у бугаїв волинської та української м'ясних порід $(\mathrm{p}<0,05)$. Найбільш чисельними за терміну зберігання 10-20 років виявилися патології головки й хвоста для сперміїв бугаїв симен- тальської, англерської і деяких м'ясних порід. Відповідно, для показників патологічних і мертвих форм сперматозоїдів бугаїв симентальської породи, молочних і м'ясних порід за терміну зберігання 10-20 років характерний середній рівень мінливості, що становить $\mathrm{Cv}, \%=7,0$ $43,7 \%$ (табл. 1, 2). Встановлено, що за терміну зберігання 21-30 років для сперматозоїдів бугаїв симентальської породи характерний вищий відсоток патологічних форм, більше сперматозоїдів із патологіями хвоста і головки в середньому на $1,8 \%$, порівняно зі сперматозоїдами бугаїв голштинської породи $(\mathrm{p}<0,05)$ (див. рис.).

Встановлено, що 3-поміж сперматозоїдів бугаїв симентальської породи за терміну зберігання 31-45 років було більше сперматозоїдів із патологіями головок у середньому на $1 \%$, аніж у сперматозоїдів бугаїв за інших термінів зберігання $(\mathrm{p}<0,05)$. Слід відмітити, що сума патологічних форм сперматозоїдів була вірогідно вища в середньому на $2,1 \%$, аніж за інших термінів зберігання. Відсоток мертвих сперміїв був вищий на $10 \%$, ніж за терміну зберігання 21-30 років (табл. 3).

Встановлено, що за терміну зберігання 31-45 років кількість мертвих клітин у бугаїв породи лімузин була вірогідно нижча (в середньому на $14,5 \%)$, аніж у спермі бугаїв інших порід $(\mathrm{p}<0,05)$. Однак, для бугаїв породи лімузин кількість мертвих сперматозоїдів й патологічних форм була вища в середньому на 7,5 \%, порівняно зі спермою бугаїв даної породи за терміну зберігання $10-20$ років $(\mathrm{p}<0,05)$ (табл. 3 ). 
2. Характеристика морфологічно-змінених форм сперматозоїдів бугаїв м'ясних порід за термінів зберігання 10-20 років, \%

\begin{tabular}{|c|c|c|c|}
\hline \multirow{2}{*}{ Вид патології спермія } & \multicolumn{3}{|c|}{ Порода $\left(\mathrm{M} \pm \mathrm{m} / \mathrm{C}_{\mathrm{v}}\right)$} \\
\cline { 2 - 4 } & лімузин & волинська м'ясна & українська м'ясна \\
\hline \multirow{2}{*}{ Мертві спермії } & $29,5 \pm 2,6^{*}$ & $35,6 \pm 1,6$ & $36,1 \pm 2,0$ \\
& 23,6 & 24,2 & 32,1 \\
\hline \multirow{2}{*}{ Патології головок } & $5,5 \pm 0,2^{*}$ & $6,7 \pm 0,2$ & $7,1 \pm 0,1$ \\
& 8,6 & 15,2 & 10,7 \\
\hline \multirow{2}{*}{ Патології хвостів } & $6,7 \pm 0,5$ & $7,2 \pm 0,2$ & $7,2 \pm 0,2$ \\
& 13,6 & 16,8 & 12,3 \\
\hline \multirow{2}{*}{ Патології шийок } & $1,4 \pm 0,2^{*}$ & $2,1 \pm 0,1$ & $1,8 \pm 0,1$ \\
\hline \multirow{2}{*}{ Патології тіл } & 23,8 & 16,7 & 7,8 \\
\hline \multirow{2}{*}{ Інші види патологій } & $2,6 \pm 0,4$ & $2,0 \pm 0,1$ & $1,9 \pm 0,1$ \\
& 44,2 & 15,9 & 11,8 \\
\hline \multirow{2}{*}{ Сума патологічних форм } & $3,7 \pm 0,1$ & $4,0 \pm 0,1$ & $3,6 \pm 0,1$ \\
& 17,1 & 15,1 & 11,5 \\
\hline
\end{tabular}

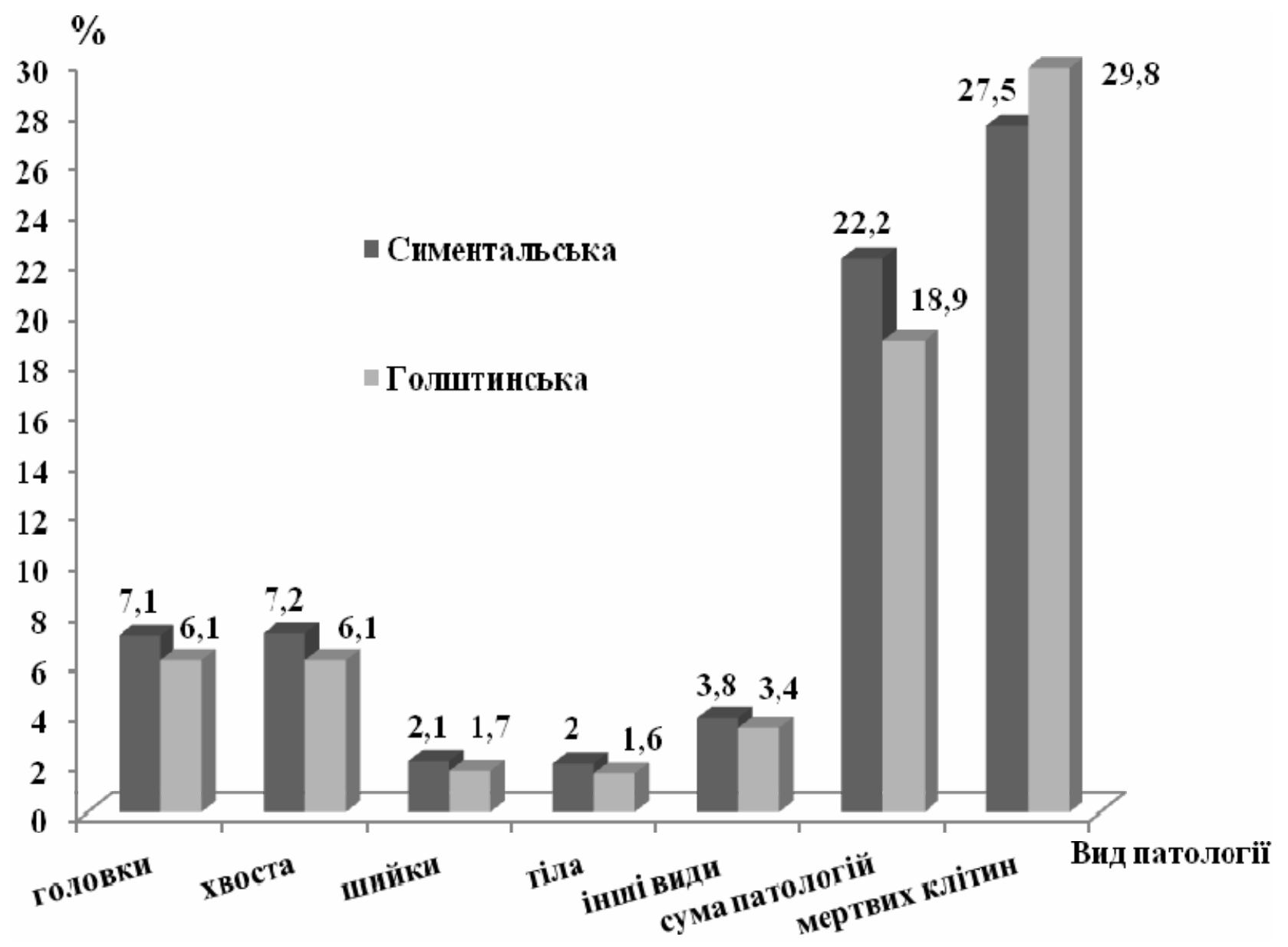

Рис. Характеристика морфологічно-змінених форм сперматозоїдів бугаӥв окремих порід за термінів зберігання 21-30 років 
СТОРІНКА МОЛОДОГО ВЧЕНОГО

\section{3. Характеристика морфологічно-змінених форм сперматозоїдів бугаїв окремих порід за термінів зберігання 31-45 років, \%}

\begin{tabular}{|c|c|c|c|c|}
\hline \multirow{2}{*}{ Вид патології спермія } & \multicolumn{4}{|c|}{ Порода $\left(\mathrm{M} \pm \mathrm{m} / \mathrm{C}_{\mathrm{v}}\right)$} \\
\cline { 2 - 5 } & симентальська & англерська & шароле & лімузин \\
\hline \multirow{2}{*}{ Мертві спермії } & $37,8 \pm 3,2$ & $29,4 \pm 2,9$ & $37,0 \pm 1,6$ & $20,2 \pm 3,2^{*}$ \\
& 29,2 & 22,0 & 10,7 & 22,7 \\
\hline \multirow{2}{*}{ Патології головок } & $8,1 \pm 0,3$ & $7,8 \pm 0,5$ & $7,7 \pm 0,3$ & $8,0 \pm 0,2$ \\
& 14,8 & 14,5 & 8,5 & 3,4 \\
\hline \multirow{2}{*}{ Патології хвостів } & $7,9 \pm 0,3$ & $7,7 \pm 0,5$ & $8,2 \pm 0,3$ & $8,4 \pm 0,6$ \\
\hline \multirow{2}{*}{ Патології шийок } & 11,8 & 13,1 & 8,9 & 10,0 \\
\hline \multirow{2}{*}{ Патології тіл } & $2,0 \pm 0,1$ & $2,0 \pm 0,1$ & $2,1 \pm 0,1$ & $2,1 \pm 0,1$ \\
& 9,6 & 10,3 & 9,1 & 6,8 \\
\hline \multirow{2}{*}{ Інші види патологій } & $2,2 \pm 0,1$ & $1,9 \pm 0,1$ & $2,1 \pm 0,1$ & $1,9 \pm 0,1$ \\
& 9,3 & 19,7 & 11,0 & 7,2 \\
\hline \multirow{2}{*}{ Сума патологічних форм } & $4,4 \pm 0,1$ & $3,7 \pm 0,1$ & $3,9 \pm 0,1$ & $4,4 \pm 0,1$ \\
& 10,2 & 8,8 & 9,0 & 13,5 \\
\hline
\end{tabular}

Висновки: 1. Встановлено, що за термінів зберігання 10-20 років спостерігалися вищі за норму значення патологічних форм сперматозоїдів у бугаїв молочних і м'ясних порід, у середньому на 2,5 \%, окрім сперми української чорнорябої молочної породи, а у спермі бугаїв симентальської та м'ясних порід (за термінів зберігання 31-45 років) вищі в середньому на $6,4 \%$.

2. Для сперми бугаїв симентальської породи, порід лімузин та шароле за терміну зберігання 31-45 років спостерігалися високі значення па-

\section{БІБЛІОГРАФІЯ}

1. Гончар О. Ф. Шляхи підвищення запліднювальної здатності сім'я бугаїв-плідників / О. Ф. Гончар, С.В. Кузебний // НТБ. - Х. : IT УАAH, 2008. - № 97. - С. 117-122.

2. Зубець М. В. Методологічні аспекти збереження генофонду сільськогосподарських тварин / М.В.Зубець, В. П. Буркат, Ю. Ф. Мельик [та ін.]; наук. ред. I. В. Гузєв. - К. : Аграрна наука, 2007. -120 с.

3. Наук B. A. Структура и функции спермиев сельскохозяйственных животных при криоконсервации. - К. : Штиинца, 1991. - 199 с.

4. Осташко Ф. И. Глубокое замораживание и длительное хранение спермы производителей / Ф. И. Осташко / К. : Урожай, 1978. - 256 с.

5. Сіраиький Й. 3. Життєздатність сперміїв від плідників різних молочних порід / Й. З. Сірацький, О. В. Бойко, С. І. Федорович // Тваринництво України, 2010. - № 3. - С. 12-16.

6. Смирнов I. В. Стан і перспективи тривалого тологічних форм (понад $24 \%$ ) та висока кількість мертвих клітин (понад $35 \%$ ). Визначено позитивний високо-вірогідний кореляційний зв'язок між кількістю патологічних і мертвих сперматозоїдів $(\mathrm{r}=0,5)$.

3. Отримані результати досліджень свідчать про необхідність періодичного моніторингу якісних показників сперми вищезазначених порід для підтвердження доцільності іiі подальшого зберігання та можливості використання в селекційному процесі.

зберігання сперми / I. В. Смирнов // Розведення та штучне осіменіння великої рогатої худоби: Респ. міжвід. тематичний наук. зб. - К. : Урожай, 1978. - Вип. 10. - С. 33-37.

7. Clement $F$. Sperm morphology and fertility / F. Clement, Y. Ladonnet, M. Magistrini // Anim. Reprod. Sci. - 2001. - № 68. - P. 362-363.

8. Dinnyes A. Novel gamete storage / A. Dinnyes, J. Liu, T. L. Nedambale // Reproduction, Fertility and Development. - 2007. - № 19. - P. 719-731. www.publish.csiro.au/journals/rfd.

9. Johnson $W$. $H$. The significance to bull fertility of morphologically abnormal sperm / W. H. Johnson // Vet. Clin. North Am. Food Anim. Pract. 1997. - № 13. - P. 255-270.

10. Soderquist $L$. Sperm morphology and fertility in A. I. bulls / L. Soderquist, L. Janson, K. Larson, S. Einarsson // J. Vet. Med. A. - 1991. - № 38(7). P. 534-543. 